\title{
Em novo suporte de memória
}

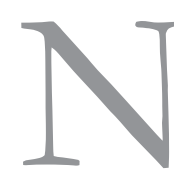

To ano em que comemora seu $20^{\circ}$. aniversário, Resgate - Revista Interdisciplinar de Cultura, concebida e produzida pelo Centro de MemóriaUnicamp (CMU), torna-se uma publicação eletrônica. Abrir mão da veiculação impressa não significa relegar a um segundo plano todo conteúdo produzido e divulgado, tanto é que todas as edições já publicadas em papel foram digitalizadas e estão acessíveis, também, na versão on-line.

O que se pretende com essa mudança de suporte é aumentar sua circulação e atingir um público acadêmico que busca informações científicas nas áreas de história, cultura, patrimônio, memória, tradição, identidade, comunicação e história oral. Nessa nova plataforma digital, Resgate mantém basicamente a estrutura que até então vem configurando a versão impressa. Em 'Apresentação' é mostrada uma vitrine sobre o conteúdo da edição, um resumo dos trabalhos contidos ressaltando sua importância no campo da reflexão. Em ‘Artigos e Ensaios', o espaço abriga textos originais oriundos de trabalhos de pesquisa. 'Combates e Rituais' é a seção reservada à publicação de resultados de teses de doutorado e de dissertações de mestrado recentemente defendidas em universidades do país e do exterior. 'Entrevista' abriga a opinião, o depoimento de cientistas e de expoentes da cultura cujas idéias contribuam e dialoguem com temas presentes na edição. 'Resenha' é o espaço reservado à apresentação e análise crítica de livros publicados nas áreas de atuação na revista. 'Crítica' abriga análise e julgamento de produções artísticas. $\mathrm{Na}$ seção 'Empório Cultural' o leitor poderá passear pelo universo da literatura, da fotografia, das artes gráficas, enfim, de produções que manifestem diferentes expressões por meio das artes.

Resgate inaugura essa nova fase produzindo uma edição temática sobre Memória e Fotografia apresentando trabalhos que revelam o caráter cada vez mais polissêmico da imagem fotográfica. Fruto de um olhar ingênuo ou crítico, asséptico ou contaminado, a fotografia em seus vários significados pode ser arte, documento, denúncia, relato, verdade, encenação, prova, história... memória. Essas e inúmeras outras definições podem ser atribuídas à fotografia. Pouco importa a definição desde que a reflexão sobre esse objeto de pesquisa e de expressão de arte e de sentimento siga pelo viés da memória. Pouco importa mesmo, desde que a 
fotografia seja um veículo que nos permita, em poucos segundos, rememorar o passado buscando informações que estavam adormecidas e reconfigurar o presente a partir da bagagem cultural de quem a observa.

Ao elaborar esta edição temática, Resgate oferece ao pesquisador e ao amante da fotografia elementos de reflexão que possibilitam aprofundar o conhecimento num campo em que não há nada mais autoral e subjetivo que o olhar pouco despretensioso do fotógrafo.
Uma nova edição temática - agora no campo da memória e do patrimônio rural - está sendo preparada, com lançamento marcado para dezembro de 2010. No entanto, edições temáticas concebidas e elaboradas por um coordenador de renome na área não se constituirão na forma exclusiva de produzir a revista. Edições generalistas - podendo ou não conter dossiês - também fazem parte do novo universo de Resgate. É só esperar.

Boa leitura!

Amarildo Carnicel, editor de Resgate 